\title{
Women's economic empowerment, participation in decision-making and exposure to violence as risk indicators for early childhood caries
}

Morenike Oluwatoyin Folayan ${ }^{1 *+}$ D, Maha El Tantawi ${ }^{2 \dagger}$, Ana Vukovic ${ }^{3}$, Robert Schroth ${ }^{4,5}$, Balgis Gaffar ${ }^{6}$, Ola B. Al-Batayneh${ }^{7}$, Rosa Amalia ${ }^{8}$, Arheiam Arheiam ${ }^{9}$, Mary Obiyan ${ }^{10}$, Hamideh Daryanavard ${ }^{11}$ and Early Childhood Caries Advocacy Group

\begin{abstract}
Objectives: In view of the association between early childhood caries (ECC])and maternal social risk factors, this study tried to determine if there were associations between indicators of processes, outputs and outcomes of women's empowerment, and the prevalence of ECC.

Methods: In this ecological study, indicators measuring the explanatory variables - economic empowerment, decision-making and violence against women - were selected from the Integrated Results and Resources Framework of the UN-Women Strategic Plan 2018-2021 and WHO database. Indicators measuring the outcome variables - the prevalence of ECC for children aged 0 to 2 years, and 3 to 5 years - were extracted from a published literature. The general linear models used to determine the association between the outcome and explanatory variables were adjusted for economic level of countries. Regression estimates (B), 95\% confidence intervals and partial eta squared $\left(\eta^{2}\right)$ were calculated.

Results: Countries with more females living under 50\% of median income had higher prevalence of ECC for 3 to 5 -year olds $(B=1.82,95 \% \mathrm{Cl}=0.12,3.52)$. Countries with higher percentage of women participating in their own health care decisions had higher prevalence of ECC for 0 to 2-year-olds ( $B=0.85,95 \% \mathrm{Cl}=0.03,1.67)$. Countries with higher percentage of women participating in decisions related to visiting family, relatives and friends had higher prevalence of ECC for 3 to 5 -year-olds ( $B=0.67,95 \% \mathrm{Cl}=0.03,1.32$ ). None of the indicators for violence against women was significantly associated with the prevalence of ECC.
\end{abstract}

Conclusion: Empowerment of women is a welcome social development that may have some negative impact on children's oral health. Changes in policies and norms are needed to protect children's oral health while empowering women.

Keywords: Early childhood caries, Women empowerment, Decision-making, Violence

\footnotetext{
* Correspondence: toyinukpong@yahoo.co.uk

${ }^{+}$Morenike Oluwatoyin Folayan and Maha El Tantawi contributed equally to

this work.

'Department of Child Dental Health, Obafemi Awolowo University, lle-lfe,

Nigeria

Full list of author information is available at the end of the article
}

(c) The Author(s). 2020 Open Access This article is distributed under the terms of the Creative Commons Attribution 4.0 International License (http://creativecommons.org/licenses/by/4.0/), which permits unrestricted use, distribution, and reproduction in any medium, provided you give appropriate credit to the original author(s) and the source, provide a link to the Creative Commons license, and indicate if changes were made. The Creative Commons Public Domain Dedication waiver (http://creativecommons.org/publicdomain/zero/1.0/) applies to the data made available in this article, unless otherwise stated. 


\section{Introduction}

Early childhood caries (ECC) is a non-communicable disease with both biological and social constructs. It affects more than 621 million children worldwide [1-3], and negatively impacts the general health and wellbeing of children [4, 5]. There is extensive literature highlighting the biological etiology and risk indicators for ECC [5-7] and a few on the family related risk factors. Maternal factors such as age and marital status [8] psychosocial status [9, 10], knowledge of oral health $[10,11]$ and oral health behavior [12, 13] are risk factors for ECC. The link between maternal health status and child oral health is well-documented $[9,12,14]$.

While there is some clarity on the association between maternal wellbeing and ECC, little is known about how social constructs of maternal wellbeing also affects the risk for ECC. One possible social construct that may affect both maternal wellbeing and the risk of a preschooler to ECC is women's empowerment status, defined as a mother having power and control over resources and decisions [15]. Several publications reported that maternal empowerment is associated with maternal survival [16-20] and child health outcomes $[21,22]$. Empowered mothers are less likely to have malnourished children [23] because they have improved diet quality diversity $[24,25]$, and support better food consumption [25]. Maternal empowerment is also associated with increased mobility that improves social networking $[26,27]$, access to health information [16, 28, 29] and access to food and medicines [30, 31].

Women's empowerment is moderated by maternal education and wealth [16]. Higher maternal education levels and economic status are associated with use of modern health facilities, contraception, preventive care, and reduced smoking [18, 32-34]. It also improves child health outcomes [24, 35-44]. Higher maternal economic status is associated with better residential locations that increase access to health services and clean environment [37, 45, 46]; predictors of infant and child morbidity and mortality [45, 47, 48].

Gender inequalities limit access of women to education, job opportunities with significant impact on their economic status [49]. This is also associated with reduced control of resources by women and the risk for abuse [50]. The concept of empowerment was developed as a holistic process to address this inequity. It acts through modifying individual women's abilities and personal choices and collective growth achieved by cultural norms [51, 52].

We conceptualize that reduced women economic empowerment decreases their decision-making ability, thereby decreasing female agency (i.e, the ability to make things happen) $[53,54]$. With decreased agency, the risk of exposure to and tolerance of violence and abuse would increase [55-57]. This impacts women in ways that reduces the ability of mothers to make health choices for the child [58-61].

In the absence of accessible evidence on the relationship between women empowerment and ECC we designed this study to determine if there is an association between women's empowerment, decision-making status, exposure to violence, and the prevalence of ECC. We hypothesized that the higher proportion of empowered women, the lower the prevalence of ECC.

\section{Methods}

Country-level data on the prevalence of ECC and women economic empowerment, decision-making and exposure to violence reported in the (Appendix A), were used for this ecological study. Figure 1 is a representation of the framework guiding the selection of indicators for this study wherein economic empowerment, decision-making ability and less exposure to violence reflect improved women's well-being that is associated with lower risk for ECC $[62,63]$. The framework was developed based on the Integrated Results and Resources Framework of the United Nations-Women Strategic Plan 2018-2021 [64]. This document included a set of indicators used to measure country progress toward women empowerment. We selected indicators measuring national individual-based performance relative to the total population (percentages) as these were more appropriate to study the micro-level relationship between women's status and ECC. Indicators related to governments or national guidelines were not used since they imply a macro-level perspective that is beyond the scope of the current study. Mean values for the years 2009 to 2017 were computed.

\section{Data on economic empowerment status}

Women's economic empowerment status was measured using five variables: owning a financial account, completing secondary school education, food insecurity, living in slums, and having an income equal to or above $50 \%$ of the median income for the country. Table 1 shows the definitions of these variables.

\section{Data on decision-making status}

Women's decision-making status was measured using the proportion of currently married women aged 15-49 years who could make four decisions about: family visits, household purchases, their own health care, and sexual health (Table 1).

\section{Data on violence against women}

Women's status on exposure and tolerance of physical violence was measured by three variables: attitude of 

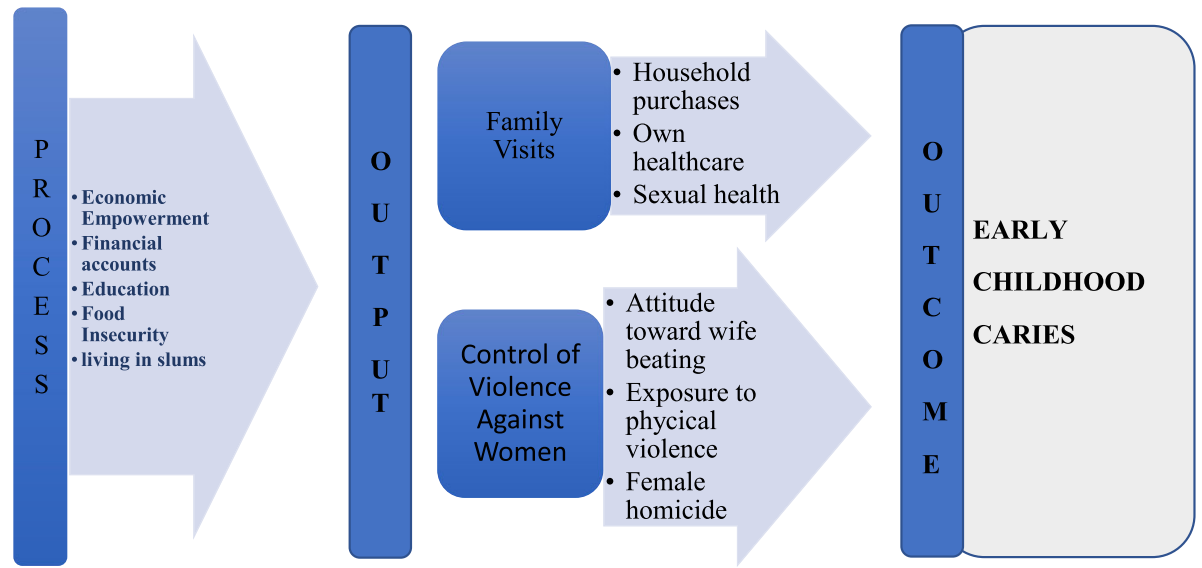

Fig. 1 The contextual framework of women empowerment process and output factors that play a role in early childhood caries outcome

Table 1 Definition and data sources of the indicators of women empowerment

\begin{tabular}{|c|c|}
\hline Variables & Definition \\
\hline \multicolumn{2}{|c|}{ ECONOMIC EMPOWERMENT } \\
\hline Education & $\begin{array}{l}\text { The percentage of female population } 25 \text { years and older who attained or completed secondary education. This data wa } \\
\text { obtained from the World Bank Databank Gender Statistics [65], based on the Global Findex database }\end{array}$ \\
\hline Food insecurity & $\begin{array}{l}\text { The percentage of females who have experienced food insecurity at moderate and severe levels during the } 12 \text { months } \\
\text { reference period. This information was obtained from the 2014-15 Food Insecurity Experience Scale survey [66]. }\end{array}$ \\
\hline Living in slums & $\begin{array}{l}\text { The proportion of women } 15-49 \text { years old who live in households that meet at least one of } 5 \text { criteria: (1) lack of access } \\
\text { to improved water source, (2) lack of access to improved sanitation facilities, (3) lack of sufficient living area, (4) lack of } \\
\text { housing durability and (5) lack of security of tenure. This was obtained from the DHS of } 60 \text { developing countries as } \\
\text { reported in the UN Women Report [67]. }\end{array}$ \\
\hline $\begin{array}{l}\text { Below } 50 \% \text { of median } \\
\text { income }\end{array}$ & $\begin{array}{l}\text { The percentage of females living below } 50 \% \text { of the median income in the country. Income is defined as total monetary } \\
\text { payments from labor, property, and social or private transfers. It also includes total value of non-monetary goods and } \\
\text { services received from labor and social or private transfers, excluding social transfers in kind such as universal health } \\
\text { insurance, universal education benefits, and near cash benefits from public housing. Data was derived from the most } \\
\text { recent Luxembourg Income Study datasets [68]. }\end{array}$ \\
\hline Financial account & $\begin{array}{l}\text { The percentage of female respondents } 15 \text { years and above, who report having their own account or together with } \\
\text { someone else at a bank or another type of financial institution. This data was obtained from the World Bank Databank } \\
\text { Gender Statistics [69], based on the Global Findex database }\end{array}$ \\
\hline
\end{tabular}

WOMEN'S DECISION-MAKING ABILITY

Family visits

Household purchase decisions

Own health care

Sexual health

The percentage of currently married women aged 15-49 years who say that they alone or jointly have the final say in visits to family, relatives, and friends [65].

The percentage of currently married women aged 15-49 years who say that they alone or jointly have the final say in making major household purchases [65].

The percentage of currently married women aged 15-49 years who say that they alone or jointly have the final say in own health care [65].

The proportion of women ages 15-49years (married or in union) who can say no to sexual intercourse with their husband or partner if they do not want, decide on use of contraception, and decide on their reproductive health care. Only women who provide a "yes" answer to all three components are considered as women who "make her own decisions regarding sexual and reproductive health" [65].

\section{CONTROL OF VIOLENCE AGAINST WOMEN}

Attitude towards wife beating

Exposure to physical violence

Female homicide
The percentage of women aged 15-49 years who believe a husband/partner is justified in hitting or beating his wife/ partner for any of the following five reasons: argues with him, refuses to have sex, burns the food, goes out without telling him, or when she neglects the children [65].

The percentage of ever partnered women aged 15-49years who were subjected to physical violence, sexual violence or both by a current or former intimate partner in the last 12 months [65].

Unlawful death inflicted upon a female with the intent to cause death or serious injury. This information was extracted from statistics by UN Office on Drugs and Crime based on national statistical systems through the annual United Nations Survey on Crime Trends and Operations of Criminal Justice Systems. The statistics reported numbers per 100,000 population [69]. 
women towards wife-beating, exposure of women to physical violence and homicide of females (Table 1).

\section{Prevalence of ECC}

The outcome variable was the prevalence of ECC. Data on ECC prevalence from 2007 to 2017 were obtained from the study by El Tantawi et al. [3]. These are data for children under 6 years of age who had one or more decayed, missing or filled primary tooth [70] split by age groups: 0 to 2 years, and 3 to 5 years. ECC prevalence data were extracted from the World Health Organization Country Oral Health Profile database, Web of Science, Scopus, Medline and Google Scholar databases using database-specific search terms. We also scanned articles published in local journals and government reports with no language filter. The retrieved country-data were used to calculate ECC prevalence per country by dividing the total number of children affected by ECC in each study by the total number of children examined and multiplying by 100 .

\section{Data analysis}

General linear models were used to assess the relationship between outcome variables - ECC in 0 to 2 year olds and ECC in 3 to 5-year-olds - and three categories of explanatory variables - indicators of economic empowerment, indicators of decision-making ability, and indicators of women exposure to violence. The models were adjusted for the economic level of countries using the World Bank list of economies for 2017. Regression estimates (B), 95\% confidence intervals (95\% C.I.) and partial eta squared $\left(\eta^{2}\right)$ were calculated. SPSS version 23 (IBM Corp., Armonk, N.Y., USA) was used for statistical analysis. Significance was set at $5 \%$.

\section{Ethical considerations}

This study did not require ethical approval as the data used were publicly available blinded data.

\section{Results}

Global level indicators of women's economic empowerment, decision-making ability, exposure to violence and ECC prevalence

Table 2 provides an overview of the data available for the study. It shows that the number of countries with available data varied: only a fifth of the 193 United Nation countries $(20.2 \%, n=39)$ had data about the percentage of females living below $50 \%$ of median income while $90.7 \%(n=175)$ countries had data on homicides per 100,000 female. The data on prevalence of ECC for $3-5$-year-olds was available in $89(57.3 \%)$ countries and that of $0-2$-year-olds was available in only $39(23.8 \%)$ countries.
Table 2 Description of indicators and ECC prevalence among countries included in the study

\begin{tabular}{|c|c|c|}
\hline Variables & $\begin{array}{l}\text { Countries with } \\
\text { available data (n) }\end{array}$ & Mean (SD) \\
\hline \multicolumn{3}{|c|}{ Economic empowerment indicators } \\
\hline Financial account & 154 & $47.8(31.6)$ \\
\hline Education & 76 & $50.9(26.4)$ \\
\hline Food insecurity & 137 & $29.8(23.2)$ \\
\hline Living in slums (\%) & 60 & $55.7(16.6)$ \\
\hline $\begin{array}{l}\text { Below } 50 \% \text { of median } \\
\text { income }\end{array}$ & 39 & $14.0(55.6)$ \\
\hline \multicolumn{3}{|c|}{$\begin{array}{l}\text { Women's Decision-making indicators: Percentage of women participat- } \\
\text { ing in decisions related to: }\end{array}$} \\
\hline Family visits & 57 & $71.3(17.9)$ \\
\hline $\begin{array}{l}\text { Household purchase } \\
\text { decisions }\end{array}$ & 58 & $62.9(19.3)$ \\
\hline Own health care & 58 & $66.1(21.7)$ \\
\hline Sexual health & 44 & $47.6(19.4)$ \\
\hline \multicolumn{3}{|l|}{ Exposure to violence } \\
\hline $\begin{array}{l}\text { Attitude towards wife } \\
\text { beating }\end{array}$ & 95 & $33.2(24.4)$ \\
\hline $\begin{array}{l}\text { Exposure to physical } \\
\text { violence }\end{array}$ & 68 & $14.9(11.4)$ \\
\hline Female homicide & 175 & $2.9(2.9)$ \\
\hline \multicolumn{3}{|l|}{ ECC prevalence } \\
\hline Among $0-2$ year-olds & 39 & $23.8(14.8)$ \\
\hline Among 3-5 year-olds & 86 & $57.3(22.4)$ \\
\hline
\end{tabular}

\section{ECC and women's economic empowerment status}

In the countries included in the analysis, $55.7 \%$ of women lived in slums, while $47.8 \%$ had financial institution accounts (Table 2). The associations between the five economic empowerment indicators and global prevalence of ECC are highlighted in Table 3. Countries with more females living under $50 \%$ of median income had a significantly higher prevalence of ECC for 3 to 5year olds $(\mathrm{B}=1.82,95 \% \mathrm{CI}=0.12,3.52)$. Meanwhile, though countries with higher percentages of educated women had higher ECC prevalence in both age groups, $(\eta 2=0.27$ and 0.05$)$ and those with higher percentages of females with food insecurity had lower ECC prevalence $\left(\eta^{2}=0.02\right.$ and 0.004$)$, these relationships were not statistically significant.

\section{ECC and women's decision-making status}

In the countries included in the study, up to $71.3 \%$ of women participated in decisions about visiting family and friends, $62.9 \%$ participated in major household purchase decisions, $66.1 \%$ participated in their own health care decisions and $47.6 \%$ made informed decisions about sexual relations and use of contraceptives (Table 2). Table 4 shows the association between the 
Table 3 Relationship between economic empowerment of women and global ECC prevalence, controlling for country economic level

\begin{tabular}{|c|c|c|c|c|c|c|}
\hline \multirow[t]{2}{*}{ Variables } & \multicolumn{3}{|c|}{ Prevalence of ECC in $0-2$ years old } & \multicolumn{3}{|c|}{ Prevalence of ECC in 3-5 years old } \\
\hline & $\begin{array}{l}\text { Countries with } \\
\text { available data (n) }\end{array}$ & $\mathrm{B}(95 \% \mathrm{Cl})$ & $\eta^{2}$ & $\begin{array}{l}\text { Countries with } \\
\text { available data (n) }\end{array}$ & $\mathrm{B}(95 \% \mathrm{Cl})$ & $\eta^{2}$ \\
\hline Financial account & $37^{a}$ & $0.05(-0.20,0.30)$ & 0.005 & $82^{f}$ & $-0.25(-0.50,0.0001)$ & 0.05 \\
\hline Education & $15^{\mathrm{b}}$ & $0.37(-0.03,0.78)$ & 0.27 & $28^{9}$ & $0.18(-0.16,0.52)$ & 0.05 \\
\hline Food insecurity & $34^{c}$ & $-0.15(-0.58,0.29)$ & 0.02 & $73^{h}$ & $-0.10(-0.47,0.27)$ & 0.004 \\
\hline Living in slums & $11^{d}$ & $0.16(-0.52,0.84)$ & 0.04 & $19^{i}$ & $-0.25(-0.93,0.43)$ & 0.04 \\
\hline Below $50 \%$ of median income & $17^{\mathrm{e}}$ & $-0.23(-2.03,1.57)$ & 0.006 & $32^{j}$ & $1.82(0.12,3.52)^{*}$ & 0.15 \\
\hline
\end{tabular}

B: Regression estimates adjusted for country income, $\mathrm{Cl}$ confidence interval, $\eta^{2}$ partial eta squared, * statistically significant at $P<0.05$

Number of countries with different economic levels included in models, LIC low-income countries, LMIC low middle-income countries, HMIC high middle-income countries, HIC high-income countries

${ }^{\mathrm{a}} \mathrm{LIC}=2, \mathrm{LMIC}=11, \mathrm{HMIC}=11, \mathrm{HIC}=15,{ }^{\mathrm{b}} \mathrm{LIC}=2, \mathrm{LMIC}=8, \mathrm{HMIC}=5, \mathrm{HIC}=\mathbf{0},{ }^{\mathrm{C}} \mathrm{LIC}=2, \mathrm{LMIC}=11, \mathrm{HMIC}=7, \mathrm{HIC}=14,{ }^{\mathrm{d}} \mathrm{LIC}=2, \mathrm{LMIC}=7, \mathrm{HMIC}=2, \mathrm{HIC}=\mathbf{0},{ }^{\mathrm{e}} \mathrm{LIC}=0$, $\mathrm{LMIC}=2, \mathrm{HMIC}=6, \mathrm{HIC}=9$

${ }^{\mathrm{f}} \mathrm{LIC}=5, \mathrm{LMIC}=19, \mathrm{HMIC}=25, \mathrm{HIC}=33,{ }^{\mathrm{g}} \mathrm{LIC}=6, \mathrm{LMIC}=13, \mathrm{HMIC}=9, \mathrm{HIC}=\mathbf{0},{ }^{\mathrm{h}} \mathrm{LIC}=5, \mathrm{LMIC}=18, \mathrm{HMIC}=20, \mathrm{HIC}=30,{ }^{\mathrm{i}} \mathrm{LIC}=5, \mathrm{LMIC}=11, \mathrm{HMIC}=3, \mathrm{HIC}=\mathbf{0},{ }^{\mathrm{j}} \mathrm{LIC}=0$, $\mathrm{LMIC}=2, \mathrm{HMIC}=9, \mathrm{HIC}=21$

four decision-making indicators and global prevalence of ECC. Countries with higher percentage of women participating in their own health care decisions had higher prevalence of ECC for 0 to 2-year-olds ( $\mathrm{B}=0.85,95 \%$ $\mathrm{CI}=0.03,1.67)$. Meanwhile, countries with higher percentage of women participating in decisions related to visiting family, relatives and friends had higher prevalence of ECC for 3 to 5 -year-olds $(\mathrm{B}=0.67,95 \% \mathrm{CI}=$ $0.03,1.32)$.

\section{ECC and women's exposure to violence}

In the countries included in the study, $33.2 \%$ of women believed husbands were justified to beat their wives and $14.9 \%$ experienced physical/sexual violence during the previous year. In the 175 countries analyzed for killing of women, 2.9 in 100,000 females were unlawfully and intentionally killed (Table 2). Table 5 shows that there were no significant associations between the three indicators of women's exposure to violence and global prevalence of ECC in countries included in the study.

\section{Discussion}

This is the first study highlighting how women's empowerment status may be a risk indicator for ECC at a global level. The study findings suggest that the prevalence of ECC for 3 to 5 -year-olds was higher where the proportion of women with $<50 \%$ of median income was greater and where the proportion of women participating in decisions about socializing was higher. We also observed that the higher the proportion of women who participated in decisions about their own health care, the higher the prevalence of ECC in 0 to 2-year-olds. No associations were identified for women's exposure to violence and ECC prevalence. Our results, therefore, partly support the study hypothesis.

We avoided the use of a summative index to describe women's empowerment because this may have obscured item-level distinctions and decrease the predictive value of the construct [24]. The results of our study justified this decision as we noticed that the prevalence of ECC was higher where one indicator of economic empowerment; females living under $50 \%$ of median income was worse and where decision-making status was better. Empowerment is a multidimensional concept and its domains are not necessarily correlated [28]. These domains are moderated by different social factors and their pathways for affecting women's empowerment and ECC may differ.

Table 4 Relationship between decision-making ability of women and global ECC prevalence, controlling for country economic level

\begin{tabular}{|c|c|c|c|c|c|c|}
\hline \multirow[t]{2}{*}{ Variables } & \multicolumn{3}{|c|}{ Prevalence of ECC $0-2$ years old } & \multicolumn{3}{|c|}{ Prevalence of ECC 3-5 years old } \\
\hline & $\begin{array}{l}\text { Countries with } \\
\text { available data (n) }\end{array}$ & $\mathrm{B}(95 \% \mathrm{Cl})$ & $\eta^{2}$ & $\begin{array}{l}\text { Countries with } \\
\text { available data (n) }\end{array}$ & $\mathrm{B}(95 \% \mathrm{Cl})$ & $\eta^{2}$ \\
\hline Family visits & $9^{a}$ & $0.90(-0.20,2.02)$ & 0.47 & $19^{c}$ & $0.67(0.03,1.32)^{*}$ & 0.25 \\
\hline Household purchase decisions & $9^{a}$ & $0.80(-0.20,1.80)$ & 0.46 & $19^{c}$ & $0.61(-0.0004,1.23)$ & 0.23 \\
\hline Own health care decisions & $9^{\mathrm{a}}$ & $0.85(0.03,1.67)^{*}$ & 0.59 & $19^{c}$ & $0.49(-0.09,1.07)$ & 0.18 \\
\hline Sexual health & $5^{b}$ & $1.69(-2.67,6.05)$ & 0.96 & $13^{d}$ & $-0.04(-1.23,1.14)$ & 0.001 \\
\hline
\end{tabular}

B: Regression estimates adjusted for country income, $C l$ confidence interval, $\eta^{2}$ partial eta squared, ${ }^{*}$ : statistically significant at $P<0.05$

Number of countries with different economic levels included in models, LIC low-income countries, LMIC low middle-income countries, HMIC high middle-income countries, HIC high-income countries

${ }^{\mathrm{a}} \mathrm{LIC}=2, \mathrm{LMIC}=5, \mathrm{HMIC}=2, \mathrm{HIC}=0,{ }^{\mathrm{b}} \mathrm{LIC}=2, \mathrm{LMIC}=2, \mathrm{HMIC}=1, \mathrm{HIC}=0,{ }^{\mathrm{C}} \mathrm{LIC}=6, \mathrm{LMIC}=9, \mathrm{HMIC}=4, \mathrm{HIC}=0,{ }^{\mathrm{d}} \mathrm{LIC}=6, \mathrm{LMIC}=5, \mathrm{HMIC}=2, \mathrm{HIC}=0$ 
Table 5 Relationship between women exposure to violence, suicide and global ECC prevalence after controlling for country economic level

\begin{tabular}{|c|c|c|c|c|c|c|}
\hline \multirow[t]{2}{*}{ Variables } & \multicolumn{3}{|c|}{ Prevalence of ECC $0-2$ years old } & \multicolumn{3}{|c|}{ Prevalence of ECC 3-5 years old } \\
\hline & $\begin{array}{l}\text { Countries with } \\
\text { available data (n) }\end{array}$ & $\mathrm{B}(95 \% \mathrm{Cl})$ & $\eta^{2}$ & $\begin{array}{l}\text { Countries with } \\
\text { available data (n) }\end{array}$ & $\mathrm{B}(95 \% \mathrm{Cl})$ & $\eta^{2}$ \\
\hline \multicolumn{7}{|l|}{ Exposure to violence } \\
\hline Attitude toward wife beating & $15^{\mathrm{a}}$ & $0.13(-0.68,0.93)$ & 0.01 & $33^{\mathrm{d}}$ & $0.05(-0.40,0.50)$ & 0.002 \\
\hline Exposure to physical violence & $14^{\mathrm{b}}$ & $0.16(-2.84,3.16)$ & 0.002 & $34^{\mathrm{e}}$ & $-0.52(-1.32,0.29)$ & 0.06 \\
\hline Female homicide & $39^{c}$ & $0.19(-1.50,1.89)$ & 0.002 & $82^{f}$ & $0.15(-1.63,1.94)$ & $<0.0001$ \\
\hline
\end{tabular}

We found conflicting associations between the prevalence of ECC and indicators of women's economic empowerment. On one hand, higher prevalence of ECC was observed where there were higher proportion of women with low income suggesting that financial empowerment was associated with less ECC as reported in prior studies [71-74]. On the other hand, the prevalence of ECC was higher where there were more educated women and food security. We feel this direct relationship between economic empowerment and the prevalence of ECC is because of women's empowerment is envisioned as their inclusion into paid labor force [75]. Access to maternity leave may enable women to support healthy eating habits and provide oral health care to infants and toddlers [76] thereby reducing their risk for ECC. On return to work, maternal care may diminish if the mother's attention becomes divided between the child and work [77, 78], negatively affecting dietary and oral hygiene habits, and increasing the risk of ECC especially for older children as the result of this study suggests.

Women's economic empowerment frameworks that value paid work and undermine the value of domestic care may have a negative impact on child oral health. Economic empowerment policies and programs may need to recognize the needs of women to have fewer hours of work outside home to enable them to care for children, and provide financial support for this home care role. The prior observation that empowerment was associated with less ECC may likely be a result of improved personal hygiene practices rather than conscious decisions about time and money allocation [79]. In addition, lower prevalence of ECC may result with changes in social norms that promote less gendered division of child caretaking responsibilities [80]. Further studies are required to evaluate how maternal economic empowerment impacts pre-school child's risk for ECC at family, community and country levels.

We also observed that the prevalence of ECC may be higher with two indictors of decision-making. We assume this may be because women with autonomous decision-making powers have greater mobility and better social networking that may result in higher exposure and access of older preschool children to processed cariogenic food [24]. On the other hand, women who are empowered to make decisions about their health may choose to plan pregnancies further apart [16] and increase the duration and frequency of breastfeeding for younger preschool children. Prolonged breastfeeding beyond 24 months of age is a risk factor for ECC in young pre-school children [81, 82]. Nevertheless, this explanation of our study findings needs further exploration.

We postulated that reduced exposure to violence arising from women's economic and social empowerment may decrease the prevalence of ECC. Violence leads to mental health challenges such as anxiety, depression, and post-traumatic stress disorder [83], which reduce maternal competency to attend to children's health including oral health [84]. Our findings did not support our postulation and did not agree with the results of few studies demonstrating negative impact of exposure of women to violence on child health [85-87]. This lack of association reported in our current study may be attributed to the relatively low prevalence of violence practices (exposure to physical/sexual violence and female homicide), which may partly explain the weak and nonsignificant association.

While our study provided new information on risk indicators for ECC, we call for caution when interpreting the findings because of few limitations. First, we were able to adjust only for country's economic level. Mutual adjustment for all the factors in the present study was not possible because of data unavailability. Adjusting for one more factor beyond the economic level reduced the sample size in some cases to zero country. We chose to provide an insight into potential relationships between ECC prevalence and indicators of women empowerment using simplified statistical models with minimal adjustment rather 
than using more comprehensive modeling technique that require data which may not be available in the foreseeable future. Also, macro-level and country-level factors affect the ability of individuals to maintain their and their family members' health. For example, regardless of the economic empowerment and decision-making ability of a woman, health services can only be accessed and utilized if available. However, we were unable to control for such countrylevel factors. In addition, we used data from global surveys such as the DHS that generally target non high-income countries (HICs). Because of this, our findings about the association between decisionmaking ability and ECC prevalence cannot be generalized to HICs. We also had few country-level data on ECC for children 0 to 2 years old, with implications for making findings for this age group not globally representative. ECC is a multifactorial disease and risk factors may differ between cultures with different practices, beliefs and traditions suggesting the need for country-specific studies prior to adoption of our study findings to guide country-level policy formulation and program development. Evidence based on individual-level data collected about the relationship between women empowerment and ECC prevalence in preschool children may support or refute our findings and thus, provide evidence for what our study suggests.

\section{Conclusion}

Despite these limitations, our study provided provisional perspective on the complex relationship between women gaining agency through economic empowerment and autonomous decision-making and the risk for ECC. Our study suggests that some measures of women empowerment may be associated with higher risk for ECC and that as women gain "power" they become victims of the pitfalls of modern western society that requires women to do more for economic comfort. This struggle may result in the relegation of homecare duties as mothers may resort to quick meals, packaged meals or sugary snacks. The study findings therefore suggest the need for safeguards for the oral health of children especially in societies with transitional economies that are working towards empowering women. Further studies are required to explore how the gaining of agency by women can reduce the risk for ECC through the institution of supportive policies that do not undermine the economic empowerment of women through mechanisms that positively influence children's caries risk behavior or through the use of resources (money and time) to acquire healthy food and oral health habits.

\section{Supplementary information}

Supplementary information accompanies this paper at https://doi.org/10. 1186/s12903-020-1045-5.

Additional file 1. Country level data on prevalence of ECC (0-2-yearolds and 3-5-year-olds), women economic empowerment, women decision-making (family visits, household purchases, their own health care, and sexual health) and women exposed to violence (attitude of women towards wife-beating, exposure of women to physical violence and homicide of females).

\section{Abbreviations}

B: Regression estimates; Cl: Confidence Interval; ECC: Early childhood caries; HIC: High-income countries; HMIC: High middle-income countries; LIC: Lowincome countries; LMIC: Low middle-income countries; PR: Prevalence Ratio; SD: Standard Deviation; $\eta^{2}$ : Partial eta squared

\section{Acknowledgements}

Not applicable.

\section{Authors' contributions}

The project was conceptualized by MOF. The project implementation was led by MOF and MET. MOF, MET, AV, RS, BG, OAB, RA, AA, MO and HD conducted the data extraction. MET conducted the data analysis. MOF wrote the first draft of the manuscript. All the authors read and contributed to several versions of the manuscript. The author(s) read and approved the final manuscript.

\section{Funding}

No grant support for this study.

Availability of data and materials

All study materials have been submitted with the manuscript.

\section{Ethics approval and consent to participate}

The study used publicly available data. Permission not required for use of these publicly available de-identified data. Not ethics clearance was required.

\section{Consent for publication}

Not applicable.

\section{Competing interests}

MOF is a Sectional Editor. MET and OBA are Associate Editors with the BMC Oral Health.

\section{Author details}

${ }^{1}$ Department of Child Dental Health, Obafemi Awolowo University, Ile-Ife, Nigeria. ${ }^{2}$ Department of Pediatric Dentistry and Dental Public Health, Faculty of Dentistry, Alexandria University, Alexandria, Egypt. ${ }^{3}$ Department of Pediatric and Preventive Dentistry, School of Dental Medicine, University of Belgrade, Belgrade, Serbia. ${ }^{4}$ Department of Preventive Dental Science, Dr. Gerald Niznick College of Dentistry, University of Manitoba, Winnipeg,

Canada. ${ }^{5}$ Departments of Pediatrics and Child Health and Community Health Sciences, Max Rady College of Medicine, Rady Faculty of Health Sciences, University of Manitoba, Winnipeg, Canada. ${ }^{6}$ Department of Preventive Dental Sciences, College of Dentistry, Imam Abdulrahman bin Faisal University, Dammam, Saudi Arabia. ${ }^{7}$ Department of Preventive Dentistry, Jordan University of Science and Technology, PO Box 3030, Irbid 22110, Jordan. ${ }^{8}$ Department of Preventive and Community Dentistry, Faculty of Dentistry, Universitas Gadjah Mada Yogyakarta, Yogyakarta, Indonesia. ${ }^{9}$ Department of Community and Preventive Dentistry, University of Benghazi, Benghazi, Libya.

${ }^{10}$ Department of Demography and Social Statistics, Obafemi Awolowo University, Ile-Ife, Nigeria. ${ }^{11}$ Dubai Health Authority, Dubai, United Arab Emirates. 
Received: 30 December 2019 Accepted: 12 February 2020 Published online: 17 February 2020

\section{References}

1. Kassebaum NJ, Bernabé E, Dahiya M, Bhandari B, Murray CJ, Marcenes W. Global burden of untreated caries: a systematic review and metaregression. J Dent Res. 2005;94(5):650-8.

2. Vos T, Flaxman AD, Naghavi M, Lozano R, Michaud C, Ezzati M, et al. Years lived with disability (YLDs) for 1160 sequelae of 289 diseases and injuries 1990-2010: a systematic analysis for the global burden of disease study 2010. Lancet. 2012:380(9859):2163-96.

3. El Tantawi M, Folayan MO, Mehaina M, Vukovic A, Castillo JL, Gaffar BO, et al. Prevalence and data availability of early childhood caries in 193 United Nations countries, 2007-2017. Am J Public Health. 2018;108(8):1066-72.

4. Bagramian RA, Garcia-Godoy F, Volpe AR. The global increase in dental caries. A pending public health crisis. Am J Dent. 2009;22(1):3-8.

5. Çolak H, Dülgergil ÇT, Dalli M, Hamidi MM. Early childhood caries update: a review of causes, diagnoses, and treatments. J Natural Sci Biol Med. 2013;4(1):29

6. Paglia L, Scaglioni S, Torchia V, De Cosmi V, Moretti M, Marzo G, Giuca M. Familial and dietary risk factors in early childhood caries introduction. Eur J Paediatr Dent. 2016;17:93.

7. Zafar S, Harnekar SY, Siddiqi A. Early childhood caries: etiology, clinical considerations, consequences and management. Int Dent SA. 2009;11(4):24-36.

8. Hallet KB, O'Rourke PK. Social and behavioural determinants of early childhood caries. Aust Dent J. 2003;48(1):27-33.

9. Seow KW. Environmental, maternal, and child factors which contribute to early childhood caries: a unifying conceptual model. Int J Paediatr Dent. 2012;22(3):157-68.

10. Finlayson TL, Siefert K, Ismail Al, Sohn W. Psychosocial factors and early childhood caries among low-income African-American children in Detroit. Community Dent Oral Epidemiol. 2007;35(6):439-48.

11. Kinirons M, McCabe M. Familial and maternal factors affecting the dental health and dental attendance of preschool children. Community Dent Health. 1995;12(4):226-9.

12. Chaffee B, Gansky S, Weintraub J, Featherstone J, Ramos-Gomez F. Maternal oral bacterial levels predict early childhood caries development. J Dent Res. 2014;93(3):238-44.

13. Retnakumari N, Cyriac G. Childhood caries as influenced by maternal and child characteristics in pre-school children of Kerala-an epidemiological study. Contemp Clin Dent. 2012;3(1):2.

14. Seow W, Clifford H, Battistutta D, Morawska A, Holcombe T. Case-control study of early childhood caries in Australia. Caries Res. 2009;43(1):25-35.

15. Malapit HJL, Kadiyala S, Quisumbing AR, Cunningham K, Tyagi P. Women's empowerment mitigates the negative effects of low production diversity on maternal and child nutrition in Nepal. J Dev Stud. 2015:51(8):1097-123.

16. Ahmed S, Creanga AA, Gillespie DG, Tsui AO. Economic status, education and empowerment: implications for maternal health service utilization in developing countries. PLoS One. 2010;5(6):e11190.

17. Fotso J-C, Ezeh A, Madise N, Ziraba A, Ogollah R. What does access to maternal care mean among the urban poor? Factors associated with use of appropriate maternal health services in the slum settlements of Nairobi. Kenya Maternal and Child Health Journal. 2009;13(1):130-7.

18. Obiyan MO, Kumar A. Socioeconomic inequalities in the use of maternal health care services in Nigeria: trends between 1990 and 2008. SAGE Open. 2015;5(4):2158244015614070.

19. Onah HE, Ikeako LC, lloabachie GC. Factors associated with the use of maternity services in Enugu, southeastern Nigeria. Soc Sci Med. 2006:63(7):1870-8.

20. Yaya S, Uthman OA, Ekholuenetale M, Bishwajit G. Women empowerment as an enabling factor of contraceptive use in sub-Saharan Africa: a multilevel analysis of cross-sectional surveys of 32 countries. Reprod Health. 2018;15(1):214

21. Shome S, Pal M, Bharati P. Influence of maternal autonomy and socioeconomic factors on birth weight of infants in India. Nutritional Status, Dietary Intake and Body Composition. 2018;24(1):35.

22. Singh K, Bloom S, Brodish P. Gender equality as a means to improve maternal and child health in Africa. Health Care for Women International. 2015;36(1):57-69.
23. Van den Bold M, Quisumbing AR, Gillespie S. Women s empowerment and nutrition: an evidence review.: Intl Food Policy Res Inst.1294; 2013.

24. Alaofè H, Zhu M, Burney J, Naylor R, Douglas T. Association between women's empowerment and maternal and child nutrition in Kalale District of northern Benin. Food Nutr Bull. 2017;38(3):302-18.

25. Malapit HJL, Quisumbing AR. What dimensions of women's empowerment in agriculture matter for nutrition in Ghana? Food Policy. 2015;52:54-63.

26. Bhagowalia P, Menon P, Quisumbing AR, Soundararajan V. What dimensions of women's empowerment matter most for child nutrition? Evidence using nationally representative data from Bangladesh. Int Food Policy Res Institute (IFPRI) Ebrary. 2015; Available at: http://thedata.harvard.edu/dvn/dv/IFPRI.

27. Smith LC, Ramakrishnan U, Ndiaye A, Haddad L, Martorell R. The importance of Women's status for child nutrition in developing countries: international food policy research institute (IFPRI) research report abstract 131. Food Nutr Bull. 2003;24(3):287-8.

28. Furuta M, Salway S. Women's position within the household as a determinant of maternal health care use in Nepal. Int Fam Plan Perspect. 2006;32:17-27.

29. Grown C, Gupta GR, Pande R. Taking action to improve women's health through gender equality and women's empowerment. Lancet. 2005; 365(9458):541-3.

30. Mainuddin A, Begum HA, Rawal LB, Islam A, Islam SS. Women empowerment and its relation with health seeking behavior in Bangladesh. J Family Reprod Health. 2015;9(2):65.

31. Shroff MR, Griffiths PL, Suchindran C, Nagalla B, Vazir S, Bentley ME. Does maternal autonomy influence feeding practices and infant growth in rural India? Soc Sci Med. 2011;73(3):447-55.

32. Caldwell J, Caldwell P. Womens position and child mortality and morbidity in less developed countries. In: Mason NFK, Sogner S, editors. Women's position and demographic change. Oxford, England: Clarendon Press; 1993. p. 122-39.

33. Allin S, Stabile M. Socioeconomic status and child health: what is the role of health care, health conditions, injuries and maternal health? Health economics. Policy and Law. 2012;7(2):227-42.

34. Dalal K, Shabnam J, Andrews-Chavez J, Mårtensson LB, Timpka T. Economic empowerment of women and utilization of maternal delivery care in Bangladesh. Int J Prev Med. 2012;3(9):628.

35. Finlay JE, Özaltin E, Canning D. The association of maternal age with infant mortality, child anthropometric failure, diarrhoea and anaemia for first births: evidence from 55 low-and middle-income countries. BMJ Open. 2011;1(2):e000226.

36. Goli S, Doshi R, Perianayagam A. Pathways of economic inequalities in maternal and child health in urban India: a decomposition analysis. PLoS One. 2013;8(3):e58573.

37. Grépin KA, Bharadwaj P. Maternal education and child mortality in Zimbabwe. J Health Econ. 2015:44:97-117.

38. Hardie $\mathrm{JH}$, Landale NS. Profiles of risk: maternal health, socioeconomic status, and child health. J Marriage Fam. 2013;75(3):651-66

39. Hobcraft JN, MCDonald JW, Rutstein SO. Socio-economic factors in infant and child mortality: a cross-national comparison. Popul Stud. 1984;38(2):193-223.

40. Mensch B, Lentzner H, Preston S. Socioeconomic differentials in child mortality in developing countries. New York: United Nations; 1985. p. 97.

41. Pongou R, Ezzati M, Salomon JA. Household and community socioeconomic and environmental determinants of child nutritional status in Cameroon. BMC Public Health. 2006;6(1):98.

42. Oyekale AS, Maselwa TC. Maternal education, fertility, and child survival in Comoros. Int J Environ Res Public Health. 2018;15(12):2814.

43. Pamuk ER, Fuchs $R$, Lutz W. Comparing relative effects of education and economic resources on infant mortality in developing countries. Popul Dev Rev. 2011:37(4):637-64.

44. Scharte M, Bolte G, Group GS. Increased health risks of children with single mothers: the impact of socio-economic and environmental factors. Eur J Public Health. 2012;23(3):469-75.

45. Case A, Lubotsky D, Paxson C. Economic status and health in childhood: the origins of the gradient. Am Econ Rev. 2002;92(5):1308-34.

46. Kunstadter P. Community, household and parental factors in rapid improvement of infant survival: Preliminary analysis of changes among hamong in thailand. Paper presented at the Annual meeting of population association of america, san francisco, April; 1995.

47. Balogun SA, Yusuff HA, Yusuf KQ, Al-Shenqiti AM, Balogun MT, Tettey P. Maternal education and child immunization: the mediating roles of maternal literacy and socioeconomic status. Pan African Med J. 2017;26:217. 
48. Luo Z-C, Wilkins R, Kramer MS. Effect of neighbourhood income and maternal education on birth outcomes: a population-based study. Can Med Assoc J. 2006;174(10):1415-20.

49. Klasen S, Lamanna F. The impact of gender inequality in education and employment on economic growth: new evidence for a panel of countries. Fem Econ. 2009;15(3):91-132.

50. United Nations Development Programme. Human development report 2015: Work for human development United Nations Development Programme 2015.

51. Huis MA, Hansen N, Otten S, Lensink R. A three-dimensional model of women's empowerment: implications in the field of microfinance and future directions. Front Psychol. 2017:8:1678.

52. United Nations Population Information Network. Guidelines for the UN Resident Coordinator System. Guidelines on Women's Empowerment. 1995; Retrieved from https://www.un.org/popin/unfpa/taskforce/guide/iatfwemp. gdl.html. April 7, 2019

53. Acharya DR, Bell JS, Simkhada P, Van Teijlingen ER, Regmi PR. Women's autonomy in household decision-making: a demographic study in Nepal. Reprod Health. 2010;7(1):15.

54. Kabeer N. (1999). Resources, agency, achievements: reflections on the measurement of women's empowerment. Dev Chang. 1999;30(3):435-64.

55. Office of Women's Health. Effects of domestic violence on children. 2019. Available at: https://www.womenshealth.gov/relationships-and-safety/ domestic-violence/effects-domestic-violence-children.

56. Koenig MA, Ahmed S, Hossain MB, Mozumder AKA. Women's status and domestic violence in rural Bangladesh: individual-and community-level effects. Demography. 2003;40(2):269-88.

57. Royal College of Psychiatrists. Domestic violence and abuse - the impact on children and adeolescents. 2017. Available at: https://www.rcpsych.ac.uk/ mental-health/parents-and-young-people/information-for-parents-andcarers/domestic-violence-and-abuse-effects-on-children

58. Devries K, Watts C, Yoshihama M, Kiss L, Schraiber LB, Deyessa N, et al. Violence against women is strongly associated with suicide attempts: evidence from the WHO multi-country study on women's health and domestic violence against women. Soc Sci Med. 2011;3(1):79-86.

59. McLaughlin J, O'Carroll RE, O'Connor RC. Intimate partner abuse and suicidality: A systematic review. Clin Psychol Rev. 2012;32(8):677-89.

60. Kavak F, Aktürk U, Özdemir A, Gültekin A. The relationship between domestic violence against women and suicide risk. Arch Psychiatr Nurs. 2018;32(4):574-9.

61. Lanier P, Maguire-Jack K, Lombardi B, Frey J, Rose RA. Adverse childhood experiences and child health outcomes: comparing cumulative risk and latent class approaches. Matern Child Health J. 2018;22(3):288-297.

62. Ersin NK, Eronat N, Cogulu D, Uzel A, Aksit S. Association of maternal-child characteristics as a factor in early childhood caries and salivary bacterial counts. J Dent Child. 2006;73(2):105-11.

63. Weinstein $\mathrm{P}$, Harrison $\mathrm{R}$, Benton T. Motivating parents to prevent caries in their young children: one-year findings. J Am Dent Assoc. 2004; 135(6):731-8.

64. Women UN. UN-Women Strategic Plan 2018-2021 - Integrated Results and Resources Framework. United Nations Entity for Gender Equality and the Empowerment of Women (UN Women), ANNEX 1; 2018.

65. The World Bank. DataBank. Gender Statistics. 2019. Available at: https://databank.worldbank.org/data/source/gender-statistics\#. Accessed 27 Apr 2019.

66. FAO. The Food Insecurity Experience Scale. FAO - Voices of the Hungry. 2019. Available at: http://www.fao.org/in-action/voices-of-thehungry/fies/en/

67. UN Women. Turning promises into action: gender eqaulity in 2030 agenda for sustainable development. Chapter 3. 2019. Available at: http://www. unwomen.org/en/digital-library/sdg-report. Accessed 27 Apr 2019.

68. Metis MIS. Meta data information system. Flow variables 2016; Available at: https://www.lisdatacenter.org/frontend\#/home. Accessed 27 Apr 2019.

69. UNODC. Intentional homicide victims by sex. 2016. Available at: https:// dataunodc.un.org/crime/intentional-homicide-victims-by-sex. Accessed 27 Apr 2019

70. AAPD. Policy on early childhood caries (ECC): classifications, consequences, and preventive strategies. Pediatric dentistry. 2008;30(7 Suppl):40.

71. Julihin A, Soares FC, Hjern A, Dahllöf G. Socioeconomic determinants, maternal health, and caries in young children. JDR Clin Trans Res. 2018;3(4):395-40.
72. Borges HC, Garbín CA, Saliba O, Saliba NA, Moimaz SA. Socio-behavioral factors influence prevalence and severity of dental caries in children with primary dentition. Braz Oral Res. 2012;26(6):564-70.

73. Oliveira LB, Sheiham A, Bönecker M. Exploring the association of dental caries with social factors and nutritional status in Brazilian preschool children. Eur J Oral Sci. 2008;116:37-43.

74. Osamor PE, Grady C. Women's autonomy in health care decision-making in developing countries: a synthesis of the literature. Int J Women's Health. 2016:8:191-202

75. Prügl E. Corporate social responsibility and the neoliberalization of feminism Gender Equality and Responsible Business; 2017. p. 56-65.

76. Berger LM, Hill J, Waldfogel J. Maternity leave, early maternal employment and child health and development in the US. Econ J. 2005;115(501):F29-47.

77. Craig L, Powell A. Non-parental childcare, time pressure and the gendered division of paid work, domestic work and parental childcare. Community Work Fam. 2013;16(1):100-19.

78. Sayer LC, Gornick JC. Cross-national variation in the influence of employment hours on child care time. Eur Sociol Rev. 2011;28(4):421-42.

79. Desai S, Johnson K. Women's Decision Making and Child Health: Familia and Social Hierarchies. In: Kishor S, editor. A Focus on Gender. Calverton MD: ORC Macro; 2005

80. Park B, Banchefsky S. Leveraging social role change to promote gender equality. Personal Soc Psychol Bull. 2018;44(9):1380-94

81. Peres KG, Nascimento GG, Peres MA, Mittinty MN, Demarco FF, Santos IS, et al. Impact of prolonged breastfeeding on dental caries: a populationbased birth cohort study. Pediatrics. 2017;140(1):e20162943.

82. Feldens CA, Rodrigues PH, de Anastácio G, Vítolo MR, Chaffee BW. Feeding frequency in infancy and dental caries in childhood: a prospective cohort study. Int Dent J. 2018;68(2):113-21.

83. van der Heijden I, Dunkle K. What works evidence review: preventing violence against women and girls with disabilities in lower- and middleincome countries (LMIC). September: UKAIDS; 2017.

84. Grumi S, Milani L, Di Blasio P. Does Intimate Partner Violence negatively impact maternal parenting? A meta-analytic review on positive parenting, harsh discipline and parenting stress. In: The 15th European Society for Traumatic Stress Studies Conference; 2017. p. 161.

85. Alhusen JL, Ray E, Sharps P, Bullock L. Intimate partner violence during pregnancy: maternal and neonatal outcomes. J Women's Health. 2015; 24(1):100-6.

86. Bogat GA, DeJonghe E, Levendosky AA, Davidson WS, von Eye A. Trauma symptoms among infants exposed to intimate partner violence. Child Abuse Negl. 2006;30(2):109-25.

87. Chai J, Fink G, Kaaya S, Danaei G, Fawzi W, Ezzati M, et al. Association between intimate partner violence and poor child growth: results from 42 demographic and health surveys. Bull World Health Organ. 2016;94(5):331.

\section{Publisher's Note}

Springer Nature remains neutral with regard to jurisdictional claims in published maps and institutional affiliations.

Ready to submit your research? Choose BMC and benefit from:

- fast, convenient online submission

- thorough peer review by experienced researchers in your field

- rapid publication on acceptance

- support for research data, including large and complex data types

- gold Open Access which fosters wider collaboration and increased citations

- maximum visibility for your research: over $100 \mathrm{M}$ website views per year

At $\mathrm{BMC}$, research is always in progress.

Learn more biomedcentral.com/submission 